\section{DIGITAL COMMONS \\ @ UNIVERSITY OF SOUTH FLORIDA}

\section{ABO: Interactive Journal for Women in the Arts, 1640-1830}

Volume 11

Issue 1 Summer 2021

Article 8

2021

\title{
A New Poem by Anna Letitia Barbauld
}

\author{
Scott Krawczyk \\ Georgetown University, sk1579@georgetown.edu \\ William McCarthy \\ wpmccarthy@bellsouth.net
}

Follow this and additional works at: https://digitalcommons.usf.edu/abo

Part of the Dramatic Literature, Criticism and Theory Commons, Educational Methods Commons, Feminist, Gender, and Sexuality Studies Commons, and the Literature in English, British Isles Commons

\section{Recommended Citation}

Krawczyk, Scott and McCarthy, William (2021) "A New Poem by Anna Letitia Barbauld," ABO: Interactive Journal for Women in the Arts, 1640-1830: Vol.11: Iss.1, Article 8.

http://doi.org/10.5038/2157-7129.11.1.1227

Available at: https://digitalcommons.usf.edu/abo/vol11/iss1/8

This Notes and Discoveries is brought to you for free and open access by Digital Commons @ University of South Florida. It has been accepted for inclusion in ABO: Interactive Journal for Women in the Arts, 1640-1830 by an authorized administrator of Digital Commons @ University of South Florida. For more information, please contact digitalcommons@usf.edu. 


\title{
A New Poem by Anna Letitia Barbauld
}

\author{
Abstract \\ Manuscript Library. \\ Keywords \\ Barbauld, poetry, new find \\ Creative Commons License \\ (c) (i) (9)
}

This short discovery article presents information pertaining to a previously unknown poem of four lines by Anna Letitia Barbauld. The poem is housed at Duke University in the David M. Rubenstein Rare Book \&

This work is licensed under a Creative Commons Attribution-Noncommercial 4.0 License

\section{Cover Page Footnote}

We thank the staff of the David M. Rubenstein Rare Book and Manuscript Library at Duke University for their assistance, especially Megan Ó Connell. 
"Undoubtedly, further poems and copies of poems remain to be discovered in manuscript archives ... not seen despite, as of 2016, a quarter century's search." So William McCarthy predicted in the Introduction to Volume One (The Poems, Revised) of The Collected Works of Anna Letitia Barbauld (1). Three months short of that volume's publication, the prediction came true. The David M. Rubenstein Rare Book and Manuscript Library at Duke University holds a manuscript leaf purchased in 2015 from Lisa Unger Baskin, a collector of women's writing; on its recto are these original lines in Barbauld's hand (Figure $1):{ }^{1}$

Born to the weighty honours of a name Whose deeds of mercy England's shores proclaim, Yet know, you may inherit lands or pelf, But must, for praise--for love, be good yourself.

A L. Barbauld August $23^{\text {rd }} 1823--$

\footnotetext{
${ }^{1}$ Searches of all relevant Gale databases, including Eighteenth Century Collections Online, produce no coincidental lines of verse. Nor do Google searches. As reliable today as many academic search engines, Google identifies the sole source as Duke University's David M. Rubenstein Rare Book \& Manuscript Library.
} 


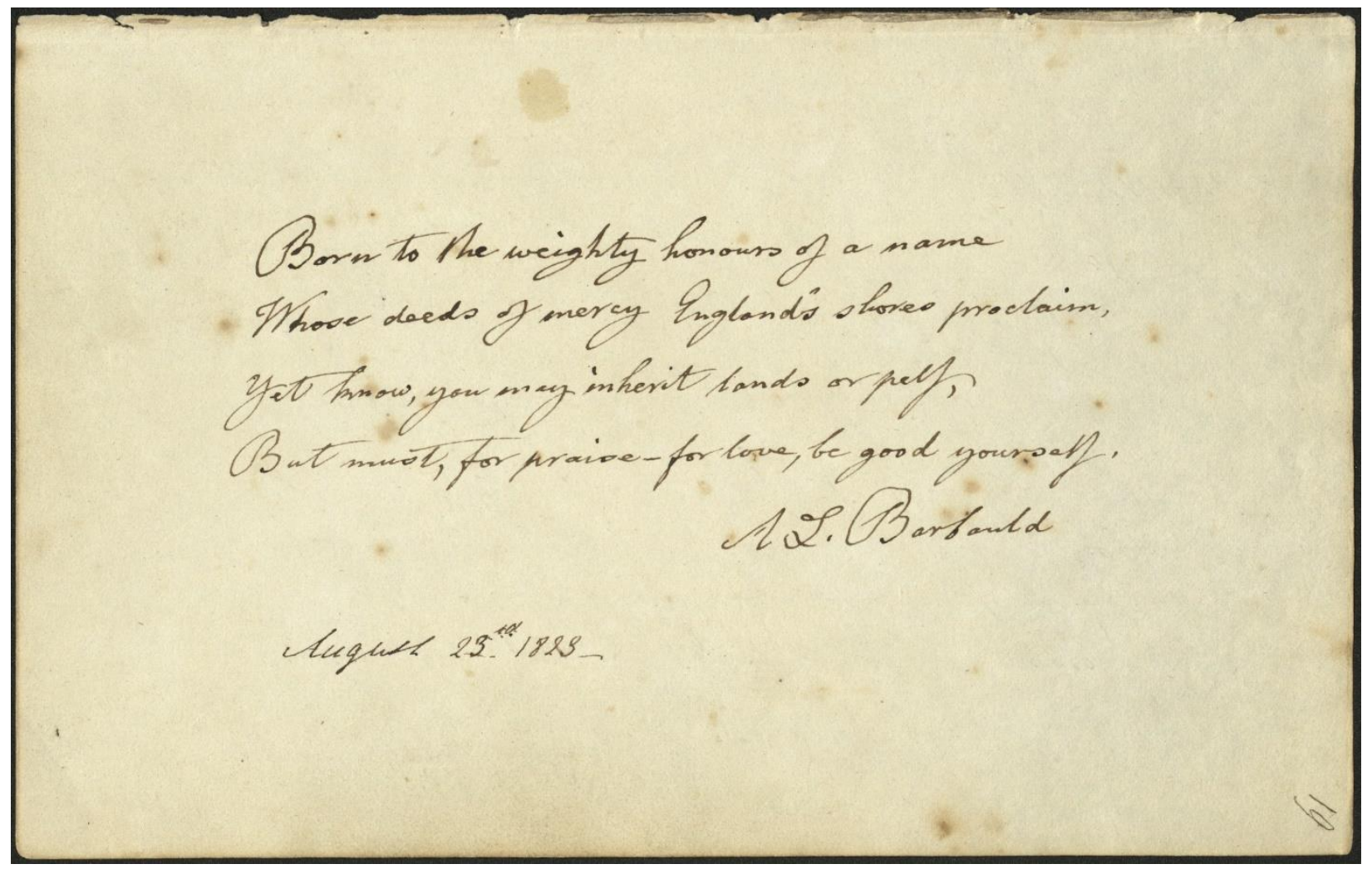

Figure 1: MS leaf of Barbauld and Allen poems [recto]- Rubenstein Collection \#RL11431/Sec. A Box 175 Folder 1. Permission of the David M. Rubenstein Rare Book \& Manuscript Library, Duke University.

The leaf's verso bears two stanzas titled "Follow me," words credited to Jesus Christ, and beginning:

Hear the Good Shepherd's gentle voice!

He calls, Richenda! calls to thee!

These lines are signed " $\mathrm{W}^{\mathrm{m}}$. Allen" and dated "Stoke newington, 30 of $8^{\text {th }}$ month 1823." 2 Barbauld lived in Stoke Newington from 1802 till her death in 1825, and one of her fellow residents there was William Allen (1770-1843), an abolitionist and patron of educationist Joseph Lancaster, a pharmacist by training, friend of Barbauld's nephew Arthur Aikin, and the " $\mathrm{W}^{\mathrm{m}}$. Allen" who inscribed the verso

\footnotetext{
${ }^{2}$ It had been given to Lisa Unger Baskin at Christmas 1983 by someone named Roy (his gift inscription is penciled along one edge of the leaf's verso). Catalogue details note that the Barbauld and Allen poems were received by the Rubenstein Library as a purchase in 2015; they were processed in April of 2017.
} 
stanzas. Barbauld and Allen were neighbors but not friends; the published text of his diary and correspondence mentions her just twice. ${ }^{3}$ They were not friends probably from religious difference: Allen was a committed Quaker, and although Barbauld's precise religious views were not well known to the public, she identified as a liberal Dissenter, and her late husband had called himself, enthusiastically, a Unitarian. Allen and Barbauld wrote their verses in Richenda's album on different visits a week apart; he could have seen hers there before he entered his. Indeed, his lines could have been a response to or comment on hers, thus: "In order to be good yourself, you must follow Jesus."

Consistent in form and size with popular autograph albums like those produced in Germany in the early nineteenth century, the leaf is pages 19 and 20 of the album to which it belonged (the numbers appear on top right on the recto and top left on the verso). Descended from sixteenth-century albums amicorum, keepsakes like this became increasingly popular among young women in nineteenth century England and America and were often kept as visiting books (Petty passim). ${ }^{4}$ Visitors would enter in them quotations or verses deemed suitable to the character or situation of the album's owner, or--as with these verses--exhortations to the album's owner. Typical of such pieces is Barbauld's "Lines written in a Young Lady's Album of Different-Coloured Paper" (Poem 155 in The Poems, Revised). The album of one Mary Anne Humble similarly contains, in Barbauld's hand, the last verse of "Epistle to Dr. Enfield on His Revisiting Warrington in 1789," lines that "may have served her as a motto when asked to inscribe something in an album" (McCarthy, The Poems, Revised 180).

As the autograph itself became a collectible, such albums also served to record encounters with notable acquaintances. And indeed, Barbauld's autograph was sought by admirers; shortly following her death, her popularity at an apex, Barbauld "became instantly a subject for a new kind of celebrity maven, the

\footnotetext{
${ }^{3}$ Both mentions occur late in Barbauld's life. For his diary entry on July 30, 1822, Allen writes, "met our neighbour Letitia Barbauld at the door, and persuaded her to come in and take tea with us" (239). On September 27, 1823, Allen "Spent the evening at Letitia Barbauld's, to meet [Sir John] Bowring" (363). Life of William Allen, with Selections from his Correspondence 3 Vols. (London: Gilpin, 1846-47).

${ }^{4}$ For their popularity among young women, see, for example: Herman Salinger, "Mathilde Heine's Album." MLN 64.6 (1949): 387-391; Lisa Reid Ricker, "(De)Constructing the Praxis of MemoryKeeping: Late Nineteenth-Century Autograph Albums as Sites of Rhetorical Invention." Rhetoric Review 29. 3 (2010): 239-256; Molly McCarthy, "A Pocketful of Days: Pocket Diaries and Daily Record Keeping among Nineteenth Century New England Women." The New England Quarterly 73.2 (2000): 274-296; and Patrizia Di Bello, "Mrs Birkbeck's Album: The Hand-written and the Printed in Early Nineteenth-Century Feminine Culture." 19: Interdisciplinary Studies in the Long Nineteenth Century 1 (2005): https://doi.org/10.16995/ntn.435.
} 
autograph collector" (McCarthy, Barbauld 527). ${ }^{5}$ Distinctive about this particular autograph of August 23, 1823, is that it bears witness to Barbauld's advanced age and weakening eyesight. In contrast to the "B" of younger signatures, with its leaner and bolder angularity, this one evinces the broader, uneven loop of a slower, more hesitant hand. The autograph bears a striking likeness to "Barbauld's late 'scrawl"' in Figure 59 of McCarthy's Anna Letitia Barbauld: Voice of the Enlightenment, leaving no doubt as to its authenticity. ${ }^{6}$

The album in question belonged to Richenda Fry, born in 1808, the fifth child of the notable prison reformer Elizabeth Fry (née Gurney) and her husband Joseph. Allen refers to being read to by Richenda in a diary entry for August 4, 1823, the very month he inscribed the "Follow Me" verses. ${ }^{7}$ Allen was friends with the Fry family; they often went to Winchmore Hill Meeting together and would sometimes dine together afterward. ${ }^{8}$ Richenda Fry would have been age 15 in 1823 , and she would indeed have been "born to the weighty honours of a name / Whose deeds of mercy England's shores proclaim." Just as Barbauld had praised famous prison reformer John Howard in Eighteen Hundred and Eleven (1. 186), here she indirectly praises Elizabeth Fry, who, like Howard before her, made her name in the cause of penal reform, particularly for women prisoners (Fry Vol. 1, passim). Allen also worked closely together with Elizabeth Fry and her brother, Joseph John Gurney, in the cause of "evangelical philanthropy" (Morton 24). Barbauld knew the Gurney family, too; the accounts for her school at Palgrave had been kept at Gurney's Bank in Norwich, and she liked the daughter, Elizabeth. Richenda Fry and her family lived at Plashet House in East Ham from 1809 to 1828 , nearly six miles east of Stoke Newington, straight-line distance. Walking or carriage distance would have been greater than seven miles. That Richenda visited Stoke Newington is unremarkable, for the village was socially and doctrinally diverse: "a very Elysian field of non-conformity," Lucy Aikin called it (Le Breton 81), and it was particularly noted for its Quaker community. ${ }^{9}$

\footnotetext{
${ }^{5}$ See also McCarthy, Anna Letitia Barbauld: Voice of the Enlightenment, p. 672, n. 34.

${ }^{6}$ In an 1817 letter to Maria Edgeworth, Barbauld apologizes for her handwriting, calling it "bad scrawl" (qtd. in LeBreton, 179). See also Anna Letitia Barbauld: Voice of the Enlightenment, p. 521. The authors have had the privilege of examining Barbauld's known extant autographs over a period of many years and were able therefore to confirm the authenticity of this one.

7 'Richenda Fry read to me a little pamphlet just published, entitled 'Hints to Mothers,' No. 1, to be continued monthly, by a disciple of Pestalozzi; it is most excellent, and ought to be widely diffused. The duties of a mother are placed in a strong light, and the good effects of the course of training there recommended, must be quite incalculable. I was affected to tears in hearing it read" (Allen, Vol. II 358).

${ }^{8}$ See entry for March 29, 1823 in Vol. 1 of Memoir of the Life of Elizabeth Fry (422), along with the corresponding entry in Vol. 2 of Life of William Allen (335 and passim).

${ }^{9}$ See "Stoke Newington Growth: Church Street," A History of the County of Middlesex: Volume 8: Islington and Stoke Newington Parishes (1985), 163-68 (URL: http://www.british-
} 
Although Barbauld remained quite sociable in later life — she "hated solitude"she was more likely to entertain visitors, "even an unsympathetic" one like Henry Crabb Robinson, than to be someone's guest (McCarthy, Barbauld 513). When she did venture outside the house, she would stay in Stoke Newington, perhaps calling on a close neighbor for conversation. Based on the distance to East Ham and Barbauld's advanced age, it is most likely that Richenda Fry called on Barbauld in Stoke Newington on that fourth Saturday in August of 1823. Given that she was fifteen at the time, the visit prompts a question: Is it possible that Richenda Fry was being mentored by Barbauld, as so many young women pupils had been? While it is true that "Barbauld's female pupils are hard to identify as pupils in part because her relations with them could be casual, seemingly just social" (McCarthy, Barbauld 492), religious difference (Elizabeth Fry was a Quaker minister), makes it doubtful that Richenda was one of those pupils. Absent a material record like the correspondence between Barbauld and Lydia Rickards, the question cannot be definitively answered. Like so many who took a pilgrimage to Barbauld's doorstep, as young Samuel Taylor Coleridge did in 1797 , and as visitors young and old did in the 1820s, probably Richenda Fry journeyed to Stoke Newington simply to meet one of the luminaries of the age. Whether she visited Barbauld for the express purpose of collecting her autograph is left to speculation. And although she was not likely to have been a pupil, Richenda Fry joined a long line of young women in receiving that small portion of Barbauld's mentorship in verse.

history.ac.uk/report.asp?compid=10024. Accessed 1 April 2006. Our thanks to Simon Martyn for this reference. 


\section{Works Cited}

Allen, William. Life of William Allen, with Selections from his Correspondence. 3 Vols. London: Gilpin, 1846-47.

Fry, Katharine and Rachel Elizabeth Cresswell, eds. Memoir of the Life of Elizabeth Fry with Journal Extracts from her Journals and Letters. 2 Vols. Montclair: Patterson Smith, 1974.

Haan, Francisca de. "Fry [née Gurney], Elizabeth (1780-1845), penal reformer and philanthropist." Oxford Dictionary of National Biography. Oxford UP Le Breton, Anna Letitia. Memoir of Mrs. Barbauld. London: Bell, 1874.

McCarthy, William. Anna Letitia Barbauld: Voice of the Enlightenment. Baltimore: JHU Press, 2008.

ed. The Collected Works of Anna Letitia Barbauld, Volume 1: The Poems, Revised. Oxford: Oxford UP, 2019.

Morton, Vanessa. Quaker Politics and Industrial Change c.1800-1850. Diss. The Open University. Web. http://oro.open.ac.uk/57260/. Date accessed: Jan 1, 2020.

Petty, Antje. “'Dies schrieb Dir zur Erinnerung. . .': From Album Amicorum to Autograph Book." Max Kade Institute, University of Wisconsin, Madison: https://web.archive.org/web/20090207045136/http://mki.wisc.edu/virtuale $\mathrm{x} /$ Stammbuecher/Stammbuecher.htm 